\title{
Developing Learning Strategies through Creative Drama
}

\author{
İsmail GÜVEN ${ }^{1}$ \\ Ankara Üniversitesi
}

\begin{abstract}
The purpose of this paper is to discuss the potential of creative drama for developing learning strategies of learners through creative drama. It is widely accepted that creative drama contributes to the learning in different domains such as cognitive, affective, psycho-motor and emotional. Learning strategies are cognitive tools that help the acquisition, storage and retrieval of information. Strategies include activities such as selecting and organizing information, rehearsing material to be learned, relating new material to information in memory, and enhancing meaningfulness of material. Strategies also include techniques that modify and determine a positive learning climate. To construct a learning strategy, learners analyze the situation and their personal characteristics, devise a plan to accomplish the learning goal, implement the plan, monitor progress and modify the plan as necessary. Metacognitive knowledge guides the operation of these steps. Learners select methods they believe will help them attain goals, such as rehearsal, elaboration, organization, comprehension monitoring, and affective techniques. It is generally accepted that strategies can make learning more efficient and effective. Therefore it is aimed here to analyze the developing learning strategies through creative drama both in formal and informal settings. For implementing learning strategies the material which is used in creative drama sessions should be organized and presented in small steps. One of the important benefits of creative drama is to provide learners with practice, feedback and review immediately. The tension and situations created in creative drama will facilitate learning and motivation which influence learning directly.
\end{abstract}

\footnotetext{
${ }^{1}$ Assoc. Prof. Dr.,Ankara University,Faculty of Educational Sciences,Department of Social Studies Teaching,iguven@education.ankara.edu.tr
} 


\section{Introduction}

Learning strategies are cognitive tools that help the acquisition, storage and retrieval of information. Strategies include activities such as selecting and organizing information, rehearsing material to be learned, relating new material to information in memory, and enhancing meaningfulness of material. Strategies also include techniques that modify and determine a positive learning climate. To construct a learning strategy, learners analyze the situation and their personal characteristics, devise a plan to accomplish the learning goals, implement the plan, monitor progress and modify the plan as necessary. Meta-cognitive knowledge guides the operation of these steps. Learners select methods they believe will help them attain goals, such as rehearsal, elaboration, organization, comprehension monitoring, and affective techniques (Schunk, 2004, p. 240). It is generally accepted that strategies can make learning more efficient and effective. Facilitating the children with suitable learning strategies is one of the most important goals in every school curricula for creating a learning society. Teachers know that not all students learn in the same way or at the same pace (Goodnough, 2001). Students have a variety of learning styles (Kolb, 1984), and therefore they respond differently to various teaching methods (Gardner, 1983). Teachers are considered as key factors in promoting learning strategies. All pedagogical arrangements should improve the quality of learning, enhance the equality of opportunities for different learners and help combat social exclusion. The common feature is a learner's active impact on learning and a learner's involvement in the learning process (Niemi, 1997). Creative drama is used widely for developing learning strategies in learning process. Learning theorists urge that more learning occurs if the students are actively participated in constituting new information and connecting it to what they already know (Good and Borophy, 2000). Learning strategies emphasize construction of the facts in learning process. Independent inquiry, and structuring and restructuring of knowledge are main components of the learning strategies .The processing of knowledge also entails a problem solving orientation, a critical approach and an evaluation of knowledge. The crucial goal of knowledge processing is that the learner can elaborate on applications of knowledge and learner may also constructs new knowledge using cognitive processes. According to the recent learning theories, quality of learning also is related to learners' abilities to direct their own learning orientation, to develop inquiring skills and to learn to reflect on and control their own learning processes. Meta-cognitive skills are key concepts (Schunk, 2000).

\section{The benefits of creative drama in developing learning strategies.}

Creative drama is itself an effective learning strategy for both content and process. Students like creative activities and are more attentive. Students better understand the process and the content if they directly involve in the process. The students are involved in "learning by doing" inquiry, making sense of the content, and students find creative drama activities memorable by discussing. Students who learn any subject through creative drama remember the activities as well as the content. Creative drama can be used to construct knowledge. Students are actively involved in searching for explanations of abstract concepts and processes, while constructing their own knowledge. Presenting scientific knowledge by creative drama means, lead to a deeper and a concrete understanding of the subject matter. Students have to show a greater degree of responsibility for their own learning (Heathcote, 1985). Students are involved in the creative drama activities as group. The students need to reflect on the experiences they gained by participating in the activities and contributing to the development of general skills - such as posing questions, building ideas, flexibility, creativity, communication, and team work that are valued in the workplace. Activities in creative drama are generally more spontaneous and more flexible than questions or discussion led by the teacher. It helps develop writing skills as well as oral skills. Creative drama enable students to define a problem, to develop solutions to a problem, to try out new solutions and new behaviors and to receive feedback. Creative drama activities generally provoke less anxiety in students than real life situations, because 
they generally represent a simplified version of reality. Designing activities helps students learn through the process of peer-teaching the concepts. The power of peer-teaching is well known by now and role play activities use it to benefit the learning process; within the role-play, the students profit from exercising their newly acquired knowledge. Discussing, rehearsing and performing the concept taught is an enjoyable and unthreatening experience (Steinert, 1993; Duveen \& Solomon, 1994; Kentish, 1995; Bailey, 1993; McCaslin, 2000, Johnson \& Johnson, 1982)

\section{What are the main strategies?}

There are many strategies for learning. The most important strategies relating to creative drama field are process based strategies such as cognitive strategies, memory strategies, compensation strategies, communication strategies, meta-cognitive strategies, affective strategies and social strategies. All these strategies can be easily developed during creative drama activities if a careful planning and adequate leadership or facilitated teachers in creative drama are available. McCaslin (2000) points out that "Of all the arts, creative drama involves the participant the most fully: intellectually, emotionally, physically, verbally, and socially. As players, children assume the roles of others, and they learn about becoming more sensitive to the problems and values of persons different from themselves. At the same time, they are learning to work cooperatively, for creative drama is a communal art; each person is necessary to the whole." Creative drama is a dynamic process. Its primary purpose is to promote personal growth and to facilitate the learning of the participants. Creative drama can also encourage language development and communication skills, promote a positive self-concept, raise social awareness and empathy, and assist in developing an understanding of the art of theatre. The aim here is to delineate the strategies which are very significant for learners. Learners may develop different strategies in creative drama sessions if it is planned carefully. Besides artistic and aesthetic gains, learners could use cognitive skills in creative drama sessions easily. It is possible to call these strategies as cognitive strategies that are composed of manipulating and transforming cognitive skills directly by means of logical thinking, taking note and functional practice in natural settings. The cognitive strategies involve using the formal practices with plots, sounds, movements, etc. Developing cognitive strategies necessities carefully note taking and reasoning during the creative drama applications.

Development of memory is essential for every kind of learning. The strategies that aimed to improve retention were paid special attention over many years.. The memory strategies are very important for learners as they provide them to store new information in memory and retrieve it later. The conventions and the nature of creative drama activities are very appropriate for developing memory strategies as the essence of creative drama is based on the prior experiences of the learners. In creative drama sessions learners should use their memory for creating new ideas and solving problems inevitably. Specifically tailored creative drama activities help learners to have new information and stimulus in memory and retrieve it later (Schunk, 2004).

Lack of compensation skills of learners is another serious problem for using learning strategies effectively. Compensation strategies are based on guess or use the symbolic language in learning. Creative drama can furnish these skills of learners by careful listening the plot or directions or writing their own text. Therefore creative drama leaders should place compensative units in creative drama sessions consciously. Normally creative drama has this dimension itself.

The other main issue for developing strategies is communication. In fact, communication is basis of every kind of activities in learning process but communication strategies as in language learning is significant if they are used by support of compensation strategies. Creative drama provides the learners to develop various communication strategies such as verbally and kinesthetic. Creative drama activities may provide learners to develop their communication strategies if they are planned purposefully for using different communication skills for learning. Using their voices and bodies, the 
learners have opportunities to express themselves in a different manner in creative drama activities. The learners try to find a creative way, which is very important for creative drama field, for achieving difficult tasks as well. Expressing themselves in a creative manner entails developing behaviors such as centering, arranging, planning and assessing the learning. All these skills are subpart of metacognitive strategies. In this phase, learners are able to improve self-control and go beyond the cognitive strategies. One of the important side of well planned creative drama activities is to direct learners to tailor strategies for using meta-cognition. In creative drama sessions, the learners are more conscious for arranging, planning and evaluation their learning than the normal teacher centered or subject centered instruction. Creative drama offers an opportunity for children to develop selfawareness and imagination, think independently and work cooperatively and build social awareness (Smilansky \& Shefatya, 1990).

Teachers may need to employ activities in which the ideas of children are drawn out in a nonthreatening manner. While involved in these activities, students may develop shared meanings, which reflect more closely on accepted instructional concepts. Teachers also should incorporate the affective domain elements into teaching and learning, so that the students will see themselves responsible for their studies. In creative drama sessions, affective strategies may develop significantly. Speaking positively and controlling emotions help learners to develop affective strategies such as self reinforcement and motivation on learning in every phase. Creative drama can help children learn about emotions and problem solving. Through their experiences with creative drama, students develop their imaginations and their confidence. Many studies also point out the affective dimension of creative drama at first step in learning (Borcih, 2000).

Of all the strategies, social strategies which contain corporation, interaction, developing empathy were accepted the significant for learning. The learners could tailor their social interactions without any pushing naturally. Therefore the social strategies dimension of creative drama is paid special attention. As the emphasis in creative drama is a process rather than product, teachers have the freedom to take as much time as needed with their classes. When a student in a creative drama class prefers to watch instead of participate, because of shyness or fear, a teacher can allow it. Furthermore the teacher can become a participant and let the children lead the activities rather than being guided through them (Fox, 1987).

\section{Developing strategies through creative drama}

The efforts of developing learning strategies that maximize learners' skills to engage in new material and identify connections with prior knowledge are desirable. Well organized creative drama sessions allow for this kind of active pupil engagement. The other benefit of creative drama is that it allows students to work closely with other who use different learning strategies and styles

\section{Creating Meanings}

Investigations have consistently shown that an emphasis on teaching for meaning has positive effects on student learning, including better initial learning, greater retention and an increased likelihood that the ideas will be used in new situations. For achieving this aim, the creative drama activities should emphasize the meanings of ideas, including how the idea, concept or skill is connected in multiple ways to real ideas in a logically consistent and sensible manner. An important factor in teaching for meaning is connecting the new ideas and skills to students' prior knowledge and experience. If carefully planned, the Creative drama activities create a classroom learning context in which students can construct meaning. One should keep in the mind that any subject taught and learned must seem reasonable to students and make sense to them. Therefore teachers or creative drama leaders should be ready for making the students catch the connections among the subjects such as language, math or science. In creative drama activities teachers or leaders should attend to student meanings and student understanding in instruction. Students' conceptions of the same idea will vary, as they have very 
different backgrounds. Teachers should build on students' intuitive notions and methods in designing and implementing instruction (Edwards \& Gandini, 2001, p. 165-166).

\section{Developing Problem Solving Skills through Creative drama}

Various studies suggest that students can learn basic concepts, skills and the structure of any subject through problem solving. In creative drama activities students face frequently the problems which are real or fictional. For developing problem solving strategies creative dramatic tension can be effective tools for implementing prior learning to new situation and learning new skills and concepts while they are working out solutions to problems. Students can learn basic concepts, skills and the main structure and context of different subjects through problem solving. In terms of creative drama, the leader or teacher make students to meet problem situation and manipulate them to use basic skills which are rooted in their individual life for transferring strategies. Development of more sophisticated skills can also be approached by treating their development as a problem for students to solve. Teachers can adapt students' informal and intuitive knowledge in other areas to develop learning strategies in creative drama sessions. The session can begin with an example for which students intuitively know the answer for a problem then the tension will expand until they found the right solutions. Students are allowed to explore and develop their own learning strategies. Teachers here are not keen on focusing the skills first they direct students to use different strategies in a creative manner for solving problems. In creative drama sessions, there are many opportunities for students to transfer their gained skills to real life by drills and rehearsals without any danger (Yaffe, 1989, p, 30-31).

\section{Developing Invention and Practice}

The big amount of the instruction time is spent to practicing routine procedures instead of developing invention strategies. This situation push the students to think automatically and monotone but not critical or creatively. They fail if the situation changes as they do not transfer their skills or knowledge new situation. However, students need opportunities for both practice and invention. Creative drama session provide students with this opportunity generally as it is based on enactment and improvisations which are not predictable easily. The studies show that students discover new connections and ideas and invent new procedures during the creative drama sessions more and they have stronger conceptual understanding (Smilansky, 1990, p. 22). Many successful creative dramaoriented lessons include time for students to practice what they have learned and discovered.

Students need opportunities to practice what they are learning and to experience performing the kinds of tasks in which they are expected to demonstrate competence. Creative drama gives them this opportunity to have their invention strategies for learning. The students act out a story or a concept they are learning or had learned before. This improvisational process allows children to analyze and synthesize information and to translate educational concepts into a personally meaningful form. In order to enhance opportunities for invention, teachers should frequently provide creative dramatic contexts with students non-routine problems, periodically introduce a lesson involving a new skill by posing it as a problem to be solved, and regularly allow students to build new knowledge based on their intuitive knowledge and informal procedures. It is always an improvised performance: lines are not written and not memorized. Each member of the group gets an opportunity to play various parts. Participants are guided by a teacher and not by a director. No decorations, costumes, or special equipment is needed, just time, space, and an enthusiastic leader.

\section{Using the Learning Strategies}

Learning strategies play a major role in the success of any workshop or learning situation, but putting on a workshop is no small matter even with a list of strategies. Knowledge of learner composition, goals and objectives, content specific issues, instructor/facilitator skills, learning 
environment, media availability, time constraints, and budget are among the many variables involved in putting together an effective creative drama workshop.

The activities of creative drama aim at activating prior knowledge relating to subjects. Remind learners of past experience that the present lesson will build on. Ask for accounts of prior experience in this domain. Pose question(s) about specific experiences that would lead to current topic, and then ask students to write (brainstorm) answers for several minutes, and then have facilitated group discussion, have someone record responses for everyone to see during discussion or rehearsal. Telling the story or the rehearsal gives the student's opportunity to describe the similarities and relevant experiences relating to current subject. Asking questions during the creative drama sessions reminds the students their prior knowledge. Early discussion or planning an enactment in creative drama provide the students to use reflection and evaluation strategies (Schunk, 2004; Pressley \& Harris, 2000).

These strategies describe ways to alert the learner about what is to come. For an effective usage of a strategy, leaders or teachers should state objectives informally. State what the learner will learn without going into specifics about the conditions and standards of performance. Then the student might overview the process slightly. Providing a pre-class newsletter and giving handouts are some important incentives which help the students to be ready for using a strategy. Starting point for a creative drama session might be leading question or dilemma for establishing the students' prior knowledge and focus the process. This orients learners to important information to follow. The discussion or elaboration phase for solving a conflict or questions in creative drama sessions will lead the students to use problem solving strategies. These are also group learning strategies. The role of leader or teacher will be facilitator. In that way teacher or creative drama leader give the students opportunities for peer learning (Duveen \& Solomon, 1994; Heathcote, 1985).

\section{Motivational Strategies}

Learners are usually ready to absorb everything we want to teach. Therefore you need to remember to show the learners why the content is relevant, interesting, or valuable. A motivation strategy should be used early in a lesson to get the learners' attention. For long lessons or for learners who are not highly motivated, additional strategies should be distributed throughout the lesson (Schunk, 2004). Creative drama sessions motivate the students for using different learning strategies. Novelty is essence of creative drama sessions. Every kind of material such as news clippings, magazine articles, or show clip from movie, is a serious reference for creative drama. Students elaborate those materials by improvising or playing. These activities make the students to use multiple senses. By working on them, students use interest and curiosity which motivate them for learning. Searching right information and discovering new connections are important learning strategies which are rooted in motivation. Arousing the uncertainty and presenting something that is contradicted what the learners know is very important in terms of the essence creative drama. Creative drama teachers or leaders make the students develop effective learning strategies if they arouse uncertainty and evoke mystery. Creative drama activities contain these units very common. Forecasting and elaboration strategies are used generally for solving a dilemma (Arieli, 2007).

Another important strategy is case study. It is important to describe someone the learners would identify with who has mastered this content. Presenting a case study may help to make a good start. Ask learners to site personal case studies. Using anecdote is very valuable for awakening storytelling strategy. Creative drama leaders or teachers should break into case studies or anecdotes small units for review, remediate, and reinforce the process. Presenting a scenario that appears to have a simple solution, asking for dialog, makes sure to highlight alternative solutions and the effect of random uncontrollable events also support the elaboration strategies. 


\section{Information Processing Strategies}

The main aim of teaching is to create a strategy enhanced environment for learning. This aim can be achieved by direct instruction, which, puts the burden of information packaging on the instructor as broadcaster of well-sequenced information or indirect instruction, puts more of the responsibility of learning on the learners themselves through inquiry and small group collaboration. Creative drama serves for realizing these aims effectively in most cases. In creative drama sessions, students interpret and analyze pictures, actions and try to encompass interaction via hands on experiences through group activities. They have opportunity to work as a team and share their solutions. This implementation helps students to develop, group working and learning strategies as well. Watching an enactment or rehearsal also is very important for students as they question the definitions and solutions by taking notes. Developing concept models is very important learning strategy in that stage. Creative drama teachers or leaders should present alternates for learners to fill in the gaps in an enactment or rehearsal. It is called also participatory strategy (Borich, 2000).

\section{Discussion/Communication Strategies}

Supporting discussion in creative drama is a key factor in terms of learning strategies. Students may use different units such as description, common purpose, procedures, possibilities, prediction, and justification, rational for reality, generalization and definitions for developing strategies. Creative drama sessions let learners provide some of the content through leader / teacher guidance by encouraging participation of the all.

The discussions that take place among the group member allow each person to speak or open dialog to entire group. The real interaction and peer working strategies are used widely. Moreover, breaking group into two or more subgroups, each with a specific perspective, providing reference materials (print or web based), allow groups to process materials and meet within group, then allow time for open debate. These implementations contribute the searching information strategies. Group discussion and brainstorming is very valuable for students. Learners work together generating ideas quickly without stopping to judge their worth. Simulating and interacting on a task are other important implementations that are appropriate for affective objectives and the development of interpersonal skills. Creating performance or enactments that require two or more participants with specific roles to present possible insights constitute using of the acting strategies. Students start to think about their role and rehearse with the other characters, then present their performance for entire group. Speaking and criticizing the performance and process cause dynamic elaborative insight and greater group interaction (Yaffe, 1989).

\section{Discussion}

Successful creative drama sessions require that teachers should plan all the details carefully. A good creative drama based lesson involves the whole class. Students must understand what they are to do and they should know what they are expected to learn from activity. Therefore teachers should facilitate learners with different problems for developing different learning strategies. It is useful to have many options for a basic situation. Thus learners can be actively involve in the process and develop their own strategies. Recognizing that they will participate to enactments or process students pay closer attention to subject or what is expected from them. They might use or prefer different strategies if they asked to act their roles in creative or different manners. For developing learning strategies, teachers or creative drama leaders should encourage the students to act out responses and be as realistic as possible. It entails teachers to intervene the creative drama process for keeping students to focus on the main idea. Teachers or creative drama leaders should lead a discussion. Teacher highlights motives and priorities of the characters and students try to use different learning strategies for responding this expectancy. For developing learning strategies, reenactment plays important role as 
it gives students opportunities to check out how they learnt and enrich their learning strategies. The discussion and debriefing of the process in creative drama sessions also gives clues about the developing the learning strategies as it aims to look over the past. By including many strategies in itself, creative drama as a method should be taken into consideration for developing learning strategies extensively.

\section{References}

Arieli, B. (2007). The Integration Of Creative drama Into Science Teaching, Unpublished Doctoral Dissertation. Curriculum \& Instruction College of Education, Kansas State University Manhattan, Kansas

Bailey, S.D. (1993). Wings to fly: Bringing theatre arts to students with special needs. Rockville, MD: Woodbine House

Borich, G.D. (2000). Effective Teaching Methods, $4^{\text {th }}$ Ed. NewYork- Merill.

Duveen, J. \& Solomon, J. (1994). The great evolution trial: Use of role-play in the classroom. Journal of Research in Science Teaching, 31 (5), 575-582.

Edwards, L. Gandini, \& G. Forman (Eds.) (2001), The hundred languages of children (pp. 161-178). Norwood, NJ: Ablex. Hendrick, J. (2001). The whole child. Columbus, OH: Merrill.

Fox, M. (1987).Teaching Creative drama to Young Children. Portsmouth, NH, Heinemann,. Gardner, H. (1993). Multiple intelligences: The theory into practice." New York: Basic Books.

Good, T. \&Borphy, J.( 2000). Looking in classrooms, 8th ed. New York, Longman.

Heathcote, D. (1985). Creative drama as education. In N. McCaslin (Ed.), Children and creative drama (2nd ed.). Lahman, MA: University Press of America.

Johnson, R.T. \& Johnson, D.W. (1982). What research says about student-student interaction in science classrooms. In M. Rowe (Ed.), Education in the 80's: Science. Washington, DC: National Education Association.

Kentish, B. (1995, March). Hypotheticals: deepening the understanding of environmental issues through ownership of learning. Australian Science Teachers Journal. 41 (1), 21-25.

Kolb, D.A. (1984). Learning style inventory. Experiential learning: Experience as the source of learning and development. Englewood Cliffs, NJ: Prentice Hall, Inc.,

Mc Caslin, Nellie (2000). Creative drama in the Classroom and Beyond, seventh edition. New York Longman,

Pressley, M. \& Harris K.R.., (1990), What We Really Know About Strategy Instruction. Educational

Leadership, March, 31-34.

Schunk, D. (2004). Learning Theories "An Educational Perspective) NewYork, Merill.,

Smilansky, S. (1990). Sociocreative dramatic play: Its relevance to behavior and achievement in school. In: E. Klugman and S. Smilansky (Eds.), Children's play and learning: Perspectives and policy implications, (pp. 18-42). NY: Teacher College Press.

Steinert, Y. (1993). Twelve tips for using role-playing in clinical teaching. Medical Teacher, 15 (4), 283-291.

Yaffe, S. H. (1989). Creative drama as a teaching tool. Educational Leadership, 46 (6), 29-32. 


\title{
Özet \\ Yaratıc1 Drama Yoluyla Ö renme Stratejilerinin Geli tirilmesi
}

\author{
İsmail GÜVEN ${ }^{2}$ \\ Ankara Üniversitesi
}

$\mathrm{Bu}$ çalışmanın amacı yaratıcı drama yoluyla öğrencilerin öğrenme stratejilerini geliştirebilmelerine yönelik uygulamaları tartışmaktır. Yaratıcı dramanın bilişsel, duyuşsal, psiko-motor ve duygusal öğrenmelere katkıda bulunduğu genel olarak Kabul edilmektedir. Öğrenilenlerin kalıcılı̆̆ının sağlanması, işe vuruk hale getirilmesinde yaratıcı dramanın önemli bir araç olduğu kabul edilmektedir. Stratejiler olumlu öğrenme ortamının gelişmesine ve oluşmasına da katkıda bulunular. Öğrenme stratejilerini uygun yer ve zamanda kullanabilmek için öğrenciler öğrenme durumlarını ve kişisel özelliklerini analiz ederek öğrenme çıktı̆̆ılarına ulaşmaya yönelik bir plan oluşturup, planı uygulamaya koyarlar. Süreci gözden geçirip öğrenmeye motive olurlar. Özellikle bilginin kalıcıllı̆̆nı artıran ve tekrar hatırlamayı sağlayan birinci elden stratejileri kullanmaya özen gösterirler. Bunu hem formal hem de informal ortamlarda kullanırlar. Öğrenme stratejilerinin geliştirilmesine en çok yardım edenler ise öğretmenlerdir. Öğrencilerin farklı öğrenme stillerini belirleyerek, hangi stratejileri kullanabilecekleri konusunda yol gösterici olabilirler. Bu nedenle sınıf içinde yapılacak olan etkinliklerin farklı öğrenme stratejilerini kullanan öğrencilerin öğrenme düzeylerini artırmaya yönelik olarak işe koşulması gerekir çünkü öğrenme stratejileri öğrenme sürecinde yaşantıların farklı biçimlerde oluşturulmasına olanak taşır. Yaratıcı drama da bir yöntem olarak, sorgulama, araştırma, keşfetme, bilgiyi yeniden oluşturma ve uygulamaya olanak verdiği için öğrenme stratejilerini geliştirebilir. Öğrenme kurumları öğrencilerin öğrenme yeteneklerini doğrudan onların öğrenme tercihlerine bağlamaktadır. Yaratıcı drama hem içerik hem de süreçte öğrenme becerilerinin gelişmesine olanak verip, öğrencilerin ön yaşantılarını öğrenme sürecine getirir. Böylece, bilginin yeniden oluşturulması ve var olan kazanımlara yöneltilmesinde kilit rol oynar. Yaratıcı drama oturumlardında öğrenciler, soru sorma, esneklik, yaratıcılık ve problem çözme gibi üst düzey bilişsel alanlarda öğrenme stratejilerini kullanmak olasıdır. Problemi tanımlayarak, olası çözüm yollarını formüle ederek öğrenciler problem çözme stratejisini etkili olarak işe koşabilirler. Aynı şekilde yaratıcı drama grupla yapılan bir etkinlik olduğu için akran öğrenmesi ve sosyal öğrenme gibi stratejileri de doğal ortamı içinde işe koşabilir. Tartışma, deneme ve sergileme gibi yaşantılar öğrencilerin öğrenmeye yönelik yeni stratejiler geliştirmesine de yardımcı olur. (Steinert, 1993; Duveen \& Solomon, 1994; Kentish, 1995; Bailey, 1993; McCaslin, 2000, Johnson \& Johnson, 1982). Yaratıcı drama oturumlarına bireyler entelektüel, duyuşsal, fiziksel ve sosyal olarak katılırlar. Böylece farklı stratejileri kullanmak için gerekli olan bütün uygulamaları yapabilirler. Yaratıcı drama oturumları özenle planlanır ve düzenlenirse, bireyler farklı öğrenme stratejilerini geliştirebilirler.

\footnotetext{
${ }^{2}$ Assoc. Prof. Dr.,Ankara University,Faculty of Educational Sciences,Department of Social Studies Teaching,iguven@education.ankara.edu.tr
} 
Örneğin mantıksal düşünme yoluluyla bilişsel öğrenme becerileri harekete geçebilir. Ön bilgilerini harekete geçirip, yeni bilgiyi alıp kullanma ve kalıcı hale getirme konusunda da hatırlama stratejilerini kullanabilirler. Yaratıcı drama oturumlarında gerçek ve hayali sorunlarla karşılaşıp bu sorunlara olası çözüm yollarını geliştirip, uygulayarak problem çözme stratejilerini işe koşabilirler. Öğrenciler Sembolik düşünme ve tahmin gibi tamamlayıcı startejiler de yaratıcı drama ortamında rahatça kullanılabilir. Yaratıcı drama oturmlarında temel alınacak stratejileri, anlamları oluşturma, problem çözme, motivasyon stratejileri geliştirme gibi üç temel başlık altında ele almak olasıdır. Anlamları oluşturma çerçevesinde bireyler yaratıcı drama oturumlarında kendileri için belirsiz olan durumları ya da kendi yaşantılarında eksik olan durumları birinci elden verilere dayalı olarak elde etebilirler. Farklı konularda kullanılan kavram ve olguları drama oturumlarında bir anda kullanabilirler (Edwards \& Gandini, 2001, p. 165-166). Yaratıcı drama oturumlarında oluşturulan çatışmaları çözerken problem çözme stratejilerini kullanılar ya da farklı çözümlere farklı stratejilerle ulaşabilirler (Yaffe, 1989, p, 30-31). Yaratıcı drama oturumlarında ortaya çıkan her durum yeni ve orjinal olduğu için bireyler normal öğretemde yaygın olan alışılmış rutinlerin dışına çıkarak, keşfetme ve yeni düşünceler oluşturmaya daha fazla zaman ayırmalarını sağlayabilir. Oluşturulan durumları doğrudan uygulama şansı buldukları için yeni düşüncelerin olası sonuçlarını hemen görerek anında dönüt alıp düzeltme yapabilirler. (Smilansky, 1990, p. 22). Yaratıcı drama oturumları yalnız strateji geliştirme değil aynı zamanda var olan öğrenme stratejilerini de uygun zaman ve mekanda kullanma olanağ da sağlar. Drama oturumlarında sorular sorarak, provalar yaparak, tartışarak farklı öğrenme stratejileri de kullınabilir. Yaratıcı drama oturumları merak ve ilginin yanısıra aktif katılımı ön plana aldığg için öğrenmeyi destekleyen motivasyon stratejilerini de öğrencilerin kullanmasına olanak verir. (Schunk, 2004; Pressley \& Harris, 2000). Yaratıcı drama oturumlarında geliştirilen bir diğer strateji ise bilgiyi elde etme işleme stratejileridir. Geleneksel öğretimde ezberlenen ve hafizada saklanması istenen bilgiler, yaratıcı drama oturumlarında doğrudan kullanılır ve yeni durumlara adapte edilir. Kavramsal modeller geliştirilebilir (Borich, 2000). Yaratıcı drama oturumlarında bireyler betimleme, tanımlama, kestirme, haklı çıkarma vb. durumları tartışma ve iletişim stratejileri bağlamında kullanarak tartışma ve etkileşim yoluyla da öğrenebilirler. Sonuç olarak unutulmaması gereken en önemli nokta yaratıcı drama liderinin (öğretmen) yaratıcı dramayı kullanırken hangi stratejiyle ne tür öğrenme çıktılarına ulaşacağına karar vermesi ve bunu uygulamaya koymasının öğrenme stratejilerini gelişitirmede önemli bir araç olduğudur. 